Original scientific paper

UDK: 327::351.88:061.1 EU (497.6)

DOI: $10.5937 / J R S 1801003 S$

Received:8 March 2018 / Accepted: 8 June 2018

\title{
The European Union and EUFOR Althea's Contribution to a Dysfunctional Peace in Bosnia and Herzegovina: Bureaucratic Politics, Emergent Strategy? \\ SIMON SWEENEY* \\ University of York, UK
}

\begin{abstract}
This article assesses the EU Common Security and Defence Policy (CSDP) in the Western Balkans, with a focus on EUFOR Althea in Bosnia and Herzegovina (BiH). Althea is a military operation that conducts mainly civilian functions as well as the training of the Bah Armed Forces; its 'civilianisation' is symptomatic of CSDP's orientation as a mainly civilian crisis management instrument. Althea works within the framework of the Union's 'comprehensive approach' to regional development and the accession process of the Western Balkans to the EU. I argue that the mission displays the bureaucratic modus operandi of CSDP and not a Grand Strategy approach. Nevertheless, CSDP's incremental, lowest-common-denominator, low cost, low risk bureaucratic politics have enabled a form of emergent strategy that complements the Union's multi-instrument and comprehensive approach to development throughout the Western Balkans. I further suggest that the EU Global Strategy (EUGS) and the newly activated Permanent Structured Cooperation (PESCO) provides opportunities for EU member states to build on low key emergent strategy to ensure that CSDP develops the substance and actorness needed to address current threats.
\end{abstract}

Keywords: Common Security and Defence Policy (CSDP), EUFOR Althea, bureaucratic politics, Grand Strategy, Bosnia and Herzegovina (BiH), civilianisation, comprehensive approach. 


\section{Introduction}

The EU Common Security and Defence Policy (CSDP) has often been judged positively in respect of its 35 missions to date, especially in the Balkans where the Union is generally perceived to have made a useful security contribution. CSDP missions are mostly successful within limited remits ${ }^{1}$, especially considering the modest costs involved $-€ 2.3 \mathrm{bn}$ in the multiannual financial framework 2014-2020, or 0.22 per cent of total EU expenditure. ${ }^{2}$ But critical assessments report variable achievement and shortcomings in speed of deployment, strategic coherence and personnel provision. ${ }^{3}$ Limited success is more achievable where ambition is low and missions are relatively small and straightforward. A review of twelve missions concluded that the Union had some way to go before it could be described as a strategic actor. ${ }^{4}$ But in the cases reviewed, missions did meet a key aim of the European Security Strategy: '(to) avert security threats, stabilise the immediate neighbourhood (and) strengthen effective multilateralism.'

Successful contribution within a multi-agency approach to post-conflict stabilisation should not hide other weaknesses. This article looks at CSDP impact in Bosnia and Herzegovina $(\mathrm{BiH})$, a post-conflict theatre where the Union has been heavily engaged, and where its flagship mission, EUFOR Althea, has been relatively expensive within the totality of CSDP. The scale of EU engagement suggests that $\mathrm{BiH}$ has always been a strategic priority for the Union, but Althea has been scaled down from its initial 7,000 troops to just 600 personnel now.

CSDP evolved as a primarily civilian-oriented conflict prevention instrument, but it is doubtful that this remains adequate given the new challenges on Europe's borders. Migration flows from the Western Balkans, including from $\mathrm{BiH}$ and Kosovo in 2016, were considerable as economic growth remained stalled across the region due to political stalemate and limited inward investment. ${ }^{7}$

This paper addresses three propositions: Grand Strategy (GS) failed to materialise and instead CSDP has evolved through bureaucratic processes; EUFOR Althea lacks a proper strategic focus consistent with the idea of GS; the mission encapsulates bureaucratic politics and despite limitations, it has contributed to an emergent EU regional strategy. The paper also traces CSDP development through a bureaucratic functionality towards, postEU Global Strategy (EUGS), a potentially more substantial presence in security affairs. I

1 Solana 2007a; Emerson and Gross 2007; Witney 2008; Menon 2009; Grevi et al. 2009; Kirchner 2013.

2 European Parliament 2016a, 1.

3 Witney 2008; Asseburg and Kempin 2009, 5-7; Berg, 2009; Mattelaer 2013.

4. Asseburg and Kempin 2009.

5 Solana 2003.

6 Asseburg and Kempin 2009, 259.

7 Euractiv 2015. 
argue that a new momentum exists through the EUGS with leadership from HRVP Mogherini and especially since a decade after its introduction in Treaty of Lisbon, the European Council sanctioned the implementation Permanent Structured Cooperation. ${ }^{8}$

The post-Lisbon CSDP consists of civilian and security-based instruments underpinned by the comprehensive approach (CA), understood as 'a stress on preventive action using a full range of EU policy tools directed towards a single target/problem (with a spectrum of tools including) military, policing, law, human rights, and economic development resources. ${ }^{9}$ The CA involves a combination of political, economic and security initiatives. The CSDP is an intrinsic component of the CA, even more so post-Lisbon given the greater proximity between Council foreign affairs interests and the Commission's role in development.

Permanent Structured Cooperation (PESCO)was meant to engage groups of willing and able member states in combined CSDP initiatives, but results proved disappointing. Lisbon reinforced state primacy in foreign and security policy, emphasising the need for unanimity, and underlining the importance of sovereign traditions and preferences, especially in respect of NATO. The Union suffered a collective loss of confidence following the Euro crisis, approximately coinciding with the launch in 2010 of the European External Action Service (EEAS), CSDP's institutional enabler. Budgetary austerity therefore meant a further squeeze on CSDP resourcing.

This article argues that EU engagement in Bosnia has reflected bureaucratic politics rather than any Grand Strategy. Nevertheless, an emergent strategy can be discerned, evidenced throughout the CSDP process, reminiscent of 'Europe as a small power. ${ }^{\prime 10}$ The paper uses substantial historical literature, including evidence from EU institutions, media commentaries, and supported by opinion from 28 semi-structured interviews conducted between 2010 and 2013 with experts involved with or close to CSDP policy making and EUFOR Althea.

We begin with commentary on Grand Strategy aspirations, followed by an explanation of bureaucratic politics applied to CSDP. The next section examines EUFOR Althea in relation to bureaucratic politics. Then the paper claims that from a bureaucratic seedbed, an emergent strategy is discernible. The conclusion asserts that EUGS and PESCO provide fresh opportunities for CSDP to achieve substance.

8 Biscop 2017.

9 Smith 2012, 265-6.

10 Toje 2008, 2011. 


\section{CSDP: Grand Strategy, or bureaucratic politics?}

Critical literature holds that CSDP requires a Grand Strategy to achieve substance. ${ }^{11}$ Substance means adequate military capability, coherence and actorness to address perceived threats. ${ }^{12}$ The ESS identified terrorism, proliferation of weapons of mass destruction (WMDs), regional conflicts, state failure and organised crime as key threats. ${ }^{13}$ This was up-dated to include cyber security and energy security ${ }^{14}$ and an emphasis on human security. ${ }^{15}$ Now new threats abound including renewed Russian militarism, the wars in Ukraine and Syria, the Middle East and North Africa (MENA) instability after the 2011 Arab Uprising, and migratory flows towards Europe.

Grand Strategy, 'the calculated relationship between means and large ends' 16 requires member states to define common interests, and to engage in state-level adaptation and therefore Europeanisation. ${ }^{17}$ It also requires institutions at the European level that are competent to deliver defence and security integration. There is therefore an association between Grand Strategy and Europeanisation, as both imply integration. GS demands intergovernmental consensus that may lead to a more federal, state-like EU. But Lisbon emphasises intergovernmentalism, and member states consistently demonstrate a lack of consensus on common interests and even on common threats, let alone on how to address these. This undermines Grand Strategy. The impact of the UK's presumed departure from the EU ('Brexit') further undermines GS since the UK and France are the only member states capable of power projection. Grand Strategy supports a comprehensive approach:

(It) refers to the collection of plans and policies that comprise the state's deliberate effort to harness political, military, diplomatic, and economic tools together to advance that state's national interest. Grand strategy is the art of reconciling ends and means. ${ }^{18}$

GS proponents have long complained that the Union has not developed an adequate strategic culture underpinned by military and civilian capability, and served by political will, ${ }^{19}$ so the EU lacks 'actorness' in this area, understood as '(the) capacity to behave actively and deliberately in relation to other actors in the international system. ${ }^{20}$

11 Biscop 2009, 2013a; Howorth 2010; Simòn 2011; Biscop and Coelmont 2010a, 2012.

12 Shepherd 2003.

13 Solana 2003.

14 European Council 2008

15 Kaldor 2007, 2012; Whitman 2013, 193.

16 Gaddis 2009.

17 Radaelli 2003.

18 Feaver 2009, 1.

19 Biscop 2009, 2010; Howorth 2010; Biscop and Coelmont 2012.

20 Sjöstedt 1977, 16. 
GS demands either top-down strategic drivers, or consensus and commitment from a significant majority of member states. Neither condition was forthcoming, but in June 2015 the Council provided fresh impetus. ${ }^{21}$ It tasked High Representative-Vice President (HRVP) Federica Mogherini with creating a 'common, comprehensive and consistent EU global strategy' 22 This ended ten years of slow progress since the 1999 Cologne Council. ${ }^{23}$ The EU Global Strategy (EUGS) arrived in June 2016 at an inauspicious moment, just days after the UK's 'Brexit' referendum. Perhaps the EUGS launch was meant as a show of unity against possible claims that the Union faced disintegration. ${ }^{24}$ The EUGS was well received by GS proponents, since it potentially offers new momentum towards common security and defence. ${ }^{25}$ But to be effective, it requires commitment, resourcing and implementation, otherwise it merely adds to the recurrent rhetoric about CFSP/CSDP.

HRVP Mogherini has effectively martialled Council, member states and Commission support for this new impetus. ${ }^{26}$ The Brexit referendum appeared to damage CSDP, the UK government has consistently underlined its commitment to European defence and security. ${ }^{27}$

A historical problem for CSDP and one that consistently undermined GS has been the veto, the 'security exemption' ${ }^{28}$ and the unanimity requirement. These ensure a prevailing minimalism, hampering any strategic shift towards CSDP achieving substance. Former HR Ashton recognised this: 'We should not delude ourselves. Lisbon left (the) CFSP as intergovernmental and subject to unanimity decision-making: (in the) absence of political will or an agreement amongst the member states there are limits to what the (EEAS) can deliver.29

The European Defence Agency (EDA)tries to enhance CSDP effectiveness by identifying pathways towards better capability and efficiency savings. ${ }^{30}$ Likewise, the EEAS provides opportunities for policy entrepreneurship. ${ }^{31} \mathrm{~A}$ third enabler is the HRVP, on which the Lisbon Treaty makes arguably excessive demands. Several observers criticised the 'multiple hats' involved, arguing that this compromised effectiveness, ${ }^{32}$ but Mogherini has won

21 European Council 2015.

22 Mogherini 2015a, 3.

23 European Council 1999a.

24. Mälksoo 2016.

25 Biscop 2016; Helly 2016; Dijkstra 2016.

26 Novotnà 2017.

27 HM Government 2017a, 2017b.

28 Treaty of Lisbon 2007, Art. 346.

29 Ashton 2013, 3 cited in Hadfield and Fiott 2014, 172.

30 Blockmans and Wessel 2009; Zwolski 2012a, 2012b.

31 Crowe 2008; Mauri and Gya 2009; Grässle 2011; Biscop 2011a; Kaunert and Léonard 2012; Dijkstra 2012b; Martin 2013; Sus 2014.

32 Grässle 2011; Dinan 2011; Hadfield and Fiott 2013; Helwig 2013; Howorth 2013. 
praise for her energetic and proactive leadership. ${ }^{33}$ Her major achievement to date, the EUGS, potentially provides for a more strategic approach. ${ }^{34}$

Bureaucratic politics is characterised by 'bargaining along regularized channels among players positioned hierarchically within the government. ${ }^{35}$ Freedman identifies an association between bureaucracy and strategy, arguing that the rise to prominence of strategy as a conceptual instrument in problem-solving is a recent phenomenon that coincides with 'the bureaucratisation of organisations, professionalisation of functions, and growth of the social sciences. ${ }^{36}$

This complements the Weberian claim that bureaucracy is a characteristic of contemporary capitalism. Much scholarly work addresses bureaucracy and bureaucratic politics. ${ }^{37}$ Lindblom referred to the 'science of muddling through' as representative of modern political process, ${ }^{38}$ echoed in later studies. ${ }^{39}$ Bickerton applies the notion of bureaucratic politics to foreign policy ${ }^{40}$ while others have specifically addressed the bureaucratic features of CDSP. ${ }^{41}$

As early as 2004, Michael Smith referred to the developing EU institutional influence in common foreign and security policy, suggesting that the traditional view of intergovernmentalism and state control over these policy fields was becoming subject to other Brussels-based pressures, including bureaucratization. ${ }^{42}$ Consolidated institutions offer potential policy entrepreneurship and may enable greater effectiveness through bureaucratic practice.

Wilson refers to bureaucracies consisting of multiple channels, complex power relationships, and ill-defined roles. ${ }^{43}$ The bureaucratic politics of CSDP operates through a hierarchy of actors and multiple components in a complex and highly networked institutional arena. According to Giddens, bureaucracy, using the Weberian conception, is a funda-

33 von Ondarza and Scheler 2017.

34 Biscop 2015.

35 Allison 1969, 970.

36 Freedman 2013, xiii.

37 Weber 1964, 1971; Giddens 1971; Mintzberg 1978, 1979; Wilson 1991; Allison 1969; Allison and Zelikow 1999; Barnett and Finnemore 1999; du Gay 2000; Kanninen and Piiparinen 2014; Urry 2008; Hartlapp et al. 2013.

38 Lindblom 1959.

39 Beetham 1987; Bossong and Benner 2010, 1079.

40 Bickerton 2011, 2013.

41 Dijkstra, 2009, 2011, 2012a; Vanhoonacker et al. 2010; Bossong and Benner 2010; Chappell and Petrov 2014.

42 Smith 2004.

43 Wilson 1991. 
mental feature of advanced societies: 'The modern capitalist state is completely dependent upon bureaucratic organisation for its existence. ${ }^{44}$

Giddens summarises the Weberian bureaucratic organisation as comprised of specialist officials appointed on the basis of technical competence evidenced by diplomas, qualifications, and experience; they perform defined functions within authoritarian and clearly demarcated hierarchies. Weber considers bureaucratic organisation as 'the most rational known means of carrying out imperative control (and) superior to any other form in precision, in stability, in the stringency of its discipline and in its reliability."${ }^{\prime 4}$

Weber's positive perspective contrasts with contemporary criticism of bureaucracy as complex, restrictive, unresponsive, and frequently dismissed as 'red tape. ${ }^{46}$ Moreover, 'according to conventional wisdom, bureaucracy stands for unnecessary and burdensome regulation' ${ }^{47}$

Weber ${ }^{48}$ suggests that specialist technical expertise and rationality explains the superiority of bureaucratic organisations over alternative forms of societal organisation, but while his formulation was based on hierarchical structures, twenty-first century post-Weberian bureaucracies are founded on the 'network logic of globalisation.' ${ }^{49}$ Bureaucracy also implies an absence of charismatic leadership or indeed any leadership, as policies emerge from decision making processes involving networks of officials and technocrats. In this way 'the power of international organisations and bureaucracies generally is that they present themselves as impersonal, technocratic, and neutral - as not exercising power but instead as serving others. ${ }^{50}$

Urry alludes to post-Weberian bureaucracies' powers, benefitting from transnational networks involving interactions between multiple actors that enable flexible and more efficient responses to emerging conflicts. ${ }^{51}$ Such processes are reflected in a seminal description of how government bureaucracies operate:

(Government organisations) are called into being by political processes; their goals, like their masters, are often diffuse; (they) are especially burdened by unique constraints; they cannot keep their profits; they have limited control over organisation of production; they have limited con-

\footnotetext{
44 Giddens 1971, 159.

45 Weber 1970, 267.

46 du Gay 2000, 1.

47 Kanninen and Piiparinen 2014, 48.

48 Weber 1964.

49 Kanninen and Piiparinen 2014, 49.

50 Barnett and Finnemore, 1999, 708.

51 Urry 2008.
} 
trol over their goals; they have external (as well as internal) goals governing their administrative procedures; and their outputs take a form that often defy easy evaluation of success or failure. ${ }^{52}$

Limited resources constrain organisations' ability to fulfil goals set by their masters and inertia sets in as the transaction costs of change increase. An inevitable characteristic of complex bureaucracies, of which armed forces are an example, is the obligation to compromise on what principals define as organisational goals. This fits with CSDP and may explain sub-optimal outcomes and even strategic incoherence. Organisations do not lack central purpose or goals, but they become prey to 'bureaucratic drift.53 They adopt norms and routines 'where satisficing is the rule stopping with the first alternative that is good enough (...) the menu of choice is severely limited and success is more likely to be defined simply as compliance with relevant rules. ${ }^{54}$

This matches the observation that CSDP reflects lowest-common-denominator agreement..$^{55}$ It is characteristic of bureaucracies that executives wish to obtain allies at a reasonable price while operators - those implementing policy - seek to cope with a situation by getting adequate commitment, guidance and resources from above. ${ }^{56}$ This is a good summation of the lowest-common-denominator impediment to strategic coherence or Grand Strategy. Allison refers to chiefs oriented around power and Indians around feasibility ${ }^{57}$ Furthermore, bureaucrats are constrained by their political masters ${ }^{58}$ They may at best 'muddle through' towards limited objectives. ${ }^{59}$ The political masters of CSDP are the PSC and member states, but bureaucratic politics does not suppose that decision making and implementation is limited to a single power node in a bureaucratic structure. Instead, policy making and implementation is highly diffuse. Various other structures, many within the EEAS, are important players in EU foreign and security policy.

Lisbon also brought the Commission into focus, especially as EU Delegations are under Commission funding and control and the Commission supports Stabilisation and Association Agreements intended as steps towards EU accession. The European Defence Agency meanwhile, vital in capability enhancement and efficient resource allocation and procurement, sits outside the EEAS.

\footnotetext{
52 Allison and Zelikow 1999, 149.

53 Ibid., 152.

54 Ibid.

55 Smith 2008, 10; Rynning 2011, 30.

56 Wilson 1991, 205.

57 Allison 1971, 176-8.

58 Wilson, 1991:13.

59 Lindblom, 1959.
} 
The developing expertise of the EEAS has led to the emergence of epistemic communities at the heart of European security policy. ${ }^{60}$ These communities of officials and technocrats contribute to the bureaucratisation of the field. A still unused CSDP instrument, the Battlegroups (BGs), also exhibit a bureaucratic process plagued by roster complexities, membership, and funding issues. ${ }^{61}$ But while they are bureaucratic and evidently have not contributed strategic actorness, BGs have brought benefits, specifically capability development, interoperability, technical cooperation and force transformation. ${ }^{62}$

A further important association with bureaucratic politics is the open method of coordination (OMC), an intergovernmental cooperative approach increasingly used to create framework directives and soft law, not the binding hard law adjudicated by the Court of Justice of the EU. ${ }^{63} \mathrm{OMC}$ carries many of the characteristics of bureaucratic politics, including reliance on technocratic assessments and lowest common denominator consensus. Together with the activation of PESCO, this offers an important way forward for the development of common security and defence policy. ${ }^{64}$

The argument so far presented can be summarised as follows. Common Foreign and Security Policy was instituted at Maastricht in the TEU as intergovernmental, ensuring state primacy in policy making. While member state authority was consolidated by the Lisbon Treaty, EU security policy and CSDP remained handicapped by a lack of strategic clarity, undermining capability development. Thus, Grand Strategy failed to emerge from any part of the CFSP. However, the field is no longer straightforwardly intergovernmental as emergent institutionalism with policy entrepreneurship especially around the EEAS has enabled evolution towards an effective if limited CSDP. It is further argued that a bureaucratic way of working involving multiple channels, similar in kind to the practice of open method of coordination in other policy fields and involving multiple actors and agencies, undermines the pure logic of intergovernmentalism. Networks and epistemic communities play an increasing role in the development of CSDP. The development and implementation of CSDP reflects processes of bureaucratic politics. The next section brings evidence from primary research to analyse EUFOR Althea, the EU's longest lasting military operation.

60 Adler and Haas 1992; Cross 2011; Bossong 2013; Pannier 2013.

61 Haine 2008.

62 Lindstrom 2007, 2011; Dickow et al. 2011; Chappell 2012; Biscop and Coelmont 2013.

63 Heidenreich and Zeitlin 2009.

64. Sweeney and Winn 2017. 


\section{EUFOR Althea and Bureaucratic Politics}

The above discussion sets the context within which EUFOR Althea operates. Interviews conducted for this research confirm the key characteristics of CSDP. A feature of CSDP's intergovernmental governance has been inertia, as initiatives are subject to member states' calculations regarding sovereignty and self-interest. States control resources and are the power brokers in mission deployment (Interviews 1, 4, 6, 7, 9, 10, 12, 14, 15, 21). Reluctance to move beyond cooperation towards integration stems from atavistic concerns over sovereignty and local protectionism, particularly regarding jobs (Interviews 2, $3,7,9,25)$. This prevents capability improvements on the scale sought by the European Defence Agency (EDA) and which Permanent Structured Cooperation (PESCO) was supposed to deliver, but did not. ${ }^{65}$ Where no actual veto is applied, the Political and Security Committee (PSC), the highest level of CSDP decision-making, may reach a consensus based on some lowest common denominator position. In this environment, GS cannot prevail even if enhanced cooperation results. An example of the latter is the Battlegroup concept. A Berlin-based think-tank expert cites capability development, interoperability, technical cooperation and force transformation as stemming from Battlegroup development (Interview 22).

Having dispensed with the notion of Grand Strategy as a viable way to progress CSDP, the field appears to depend on an alternative approach to its evolution that has characterised the process from the beginning, namely CSDP's gradualist, incremental and low risk development through bureaucratic politics. This epitomises how CSDP works (Interviews $5,7,26,27$ ), especially since the EEAS was set up. From within the EEAS, Civilian Management and Planning Directorate (CMPD) and Secretariat officials comment on the increasing expertise of the service and its role in developing epistemic communities (Interviews 13, 9). The EEAS has proved an embryonic institutional enabler, with increasing influence over common foreign and security policy (Interviews 4, 5, 8, 9, 12). But ultimately CSDP depends on state-level decision-making through state-appointed ambassadors in the PSC. Once they authorise a mission, effectiveness depends on adequate and timely resourcing by member states, ever the central arbiters. After 2010, limited resources have been further squeezed by the imposition of austerity (Interviews 10, 11, 24, 26).

EUFOR Althea has been the largest and longest running CSDP military operation, now in its fourteenth year. Bosnia and Herzegovina $(\mathrm{BiH})$ presents a challenging post-conflict environment with a high level of political and economic dysfunction. Althea accounts for only a tiny proportion of the total CFSP annual spend of $€ 327 \mathrm{~m}$ in 2016 . Military operations are paid for by the participating states on a 'costs lie where they fall' basis, except that common costs are met through the Athena mechanism whereby member states pay in proportion to their gross domestic income. Althea's common costs drawn from the

65 Biscop and Coelmont 2010b, 2011; EDA 2014a. 
CFSP/CSDP budget amount to a modest $€ 10 \mathrm{~m}$ annually. ${ }^{66}$ Official estimates are that the EU meets around 10-15 per cent of the total costs of a CSDP military operation. ${ }^{67}$

Bosnia signed a Stabilisation and Association Agreement (SAA) with the EU in June $2015{ }^{68}$ This is significant because SAAs apply a comprehensive approach using multiple instruments within a strategic, long term framework. ${ }^{69} \mathrm{~A}$ major political challenge in $\mathrm{BiH}$ is to prevent state institutions falling prey to corrupt politicians and officials. CSDP implementation has not protected Bosnia from the malign influence of nationalists and former combatants who have assumed prominent positions in state institutions. A Balkans expert expressed the Weberian view that bureaucracy and the emergence of bureaucratic institutions would be a better state-building outcome than the capture of the state, or any constituent parts, by nationalists with blood on their hands (Interview 27). However, the Bosnian situation remains precarious given the lack of progress in both socio-economic development and in establishing a political environment free from atavistic and sectarian nationalism. Indeed, EUFOR Althea recognises the acute challenges, noting the lack of commitment to federal institutions among political leaderships and the tendency for elections to be conducted along ethno-nationalist lines. ${ }^{70}$

EU post-conflict stabilisation and development efforts have brought clear benefits across the Balkans. ${ }^{71}$ On the other hand, others suggest a varied assessment with Bosnia and Kosovo still presenting major challenges, ${ }^{72}$ whereas other ex-Yugoslav territories have made more progress, most obviously Slovenia and Croatia which joined the EU in 2004 and 2013 respectively. However, the implementation of an SAA for $\mathrm{BiH}$ is consistent with the ambitions of the comprehensive approach and with CSDP objectives.

The EU strategic aim is to stabilise the Western Balkans and to progress all constituent states towards candidacy and eventual Union accession. But Bosnia and Kosovo remain a long way from this goal. It is difficult to describe EU engagement in either as strategically successful while state dysfunction in both remains entrenched. ${ }^{73}$ Recent reports of arms shipments to the Republika Srpska police and Russian-trained mercenaries working with paramilitary groups have brought new fears of a return to violence. ${ }^{74}$ The EU High Representative for $\mathrm{BiH}$, Valentin Inzko, expressed alarm at the purchase of 2,500 automatic rifles, saying the entire police weapons count in his native Austria did not exceed 400 .

66 Boštjančič Pulko et al. 2016.

67 Di Mauro et al. 2017, 8; European Parliament 2016b.

68 European Commission 2015a.

69 Watanabe 2010.

70 EUFOR Althea 2017.

71 BBC News 2013; EEAS 2013b; Radio Free Europe 2013; Peen Rodt and Wolff 2012; Kirchner 2013.

72 Gross and Rotta 2011; Biermann 2014; European Commission 2015b, 2015c.

73 Boštjančič Pulko et al. 2016; Capussela 2015a, 2015b; Jaqué 2015; European Commission 2015b.

74 Guardian, 2018a, 2018b. 
There are also reports of paramilitary activity among Islamist factions within the BosnianCroat Federation. ${ }^{75}$ Perhaps the diminished scale of EUFOR Althea makes a new belligerence more likely among nationalist factions, bringing inherent risks. Activity such as that reported makes the task of a reduced EUFOR Althea more difficult, but also more vital, as the operation plays an 'eyes and ears' role, monitoring risk. There is concern among the international community that Russian interests may destabilise $\mathrm{BiH}$ and the region, especially as Serbia appears to be developing trade, energy and weapons deals with Moscow, anathema to the EU, other Balkan states, and the USA. ${ }^{76}$

EUFOR Althea was launched in 2004 under a UN mandate, an EU operation on behalf of and reflecting the will of the international community. There have been no deaths from armed violence since EUFOR replaced SFOR in December 2004. It successfully fulfils its original mandate to uphold the Dayton Peace Agreement ${ }^{77}$ drawn up to end the war, and it has continued to contribute to a safe and secure environment (Interviews 15-21). The mission has garnered a generally positive assessment from the academic community ${ }^{78}$ and from governmental and EU sources. ${ }^{79}$ But caution should be exercised in declaring the EU presence in $\mathrm{BiH}$ comprehensively successful. Overhaus refers to a 'frozen conflict ${ }^{\prime 80}$ that requires strategic effort from the EU and member states and the ability to intervene militarily if necessary. The Commission judged Bosnia's accession process to be 'at a standstill' in $2014^{81}$ but the 2015 Stabilisation and Accession Agreement represented progress. ${ }^{82}$ While EUFOR Althea was further extended in 2015 and 2016there are no illusions about the scale of difficulty still apparent..$^{83}$ The main objectives of EUFOR Althea are to provide the Armed Forces of $\mathrm{BiH}(\mathrm{AFBiH})$ with capacity-building and training, to support the entire EU strategy in the country and to maintain a secure and safe environment by providing support to all efforts on the ground geared towards that process. ${ }^{84}$ The operation can be evaluated as partially successful and efficient especially in the context of its relatively low cost (Interviews, 12, 18). ${ }^{85}$

75 Knezevic 2018.

76 Irish Times 2017.

77 OHR 1995.

78 Gross 2007; Keohane 2009, 218; Merlingen 2013, 150; Whitman and Juncos 2009-2014; Kirchner 2013; Boštjančič Pulko et al. 2016.

79 Foreign and Commonwealth Office 2007; Hansard 2008; European Council 2010; Council of the European Union 2010; European Commission 2014, 2015b.

80 Overhaus 2009, 28.

81 European Commission 2014, 1.

82 European Commission 2015a.

83 United Nations 2015, 2016; EU Delegation BiH 2017; European Commission 2015c.

84. EUFOR Althea 2017, 2018.

85 Boštjančič Pulko et al. 2016. 
Althea's 'civilianisation' is an indication of this partial success (Interviews 15,16), reflecting a more stable security situation, albeit one inherited from SFOR, and one to which various instruments and organisations contribute. ${ }^{86}$ In the absence of a sustained threat, the mission's main function has been reassurance. ${ }^{87}$ Althea has enjoyed local support, ${ }^{88}$ and despite reduced strength it contributes to a safe and secure environment. ${ }^{89}$ Historic achievements include weapons harvesting, intelligence gathering, patrolling, tracking and catching indicted war criminals, combating organised crime and supporting local law enforcement agencies, including training and capacity building for the $\mathrm{BiH}$ Armed Forces, now better equipped to take on stabilisation and security responsibilities across the country. Undoubted achievements should not obscure shortcomings that have implications for CSDP and EU aspirations for the region. $\mathrm{BiH}$ state dysfunction remains endemic and casts doubt on whether the EU engagement can be described as a strategic success. Various scholars confirm alarming levels of dysfunction, instability and political stagnation..$^{90}$

Meanwhile Commission reports after the SAA are downbeat on political and economic reform, noting only limited progress in most areas, including public administration, justice system, dealing with corruption, fighting organised crime, human rights and the rights of minorities, and in economic criteria including establishing a functioning market economy. ${ }^{91}$

CSDP implementation in $\mathrm{BiH}$ reflects the minimalist, lowest-common-denominator, issue-by-issue characteristics of the initiative (Interviews 1, 8, 9, 12, 13, 28). It depends on limited resources and weak commitment from Member States. ${ }^{92}$ The threat in 2004 was that Bosnia could revert to chaos or become a seedbed for regional violence, a threat which has not gone away and may even have grown with the emergence of DAESH/ISIS, which Europol suggests may have established training camps in the Balkans. ${ }^{93}$ Althea is a post-conflict peacekeeping operation, now comprising a mere 600 personnel from 17 EU Member States and five partner nations. ${ }^{94}$ The majority are from Austria, Hungary, and non-EU member, Turkey - a curious reflection of the country's history. Chappell and Petrov describe Althea as a manifestation of EU strategic interest in the Western Balkans to establish peace and security ${ }^{95}$ but Althea officials criticise the lack of an adequately strategic approach (Interviews 15-21). This seems harsh given the context of enlargement policy, the Stability Pact for South East Europe and $€ 13.1$ bn of regional investment

86 Ibid.

87 Bertin 2008, 67; Overhaus 2009, 21.

88 Bertin, 2008:67.

89 Gross 2015; Boštjančič Pulko et al. 2016.

90 Gross 2007; McMahon and Western 2009; Whitman and Juncos 2009-2014.

91 European Commission 2016.

92 Boštjančič Pulko et al. 2016.

93 Telegraph 2016.

94 EEAS 2014; EUFOR Althea 2017.

95 Chappell and Petrov 2014. 
between 2008 and 2014 from the Western Balkans Investment Framework. ${ }^{96}$ But critical opinion suggests a lack of a clear exit strategy and no defined and measurable outcomes as on-going weaknesses in EUFOR Althea's BiH engagement. ${ }^{97}$

Klein reports that the former mission commander General Leakey, backed by former HR Solana, saw the fight against organised crime and providing a safe and secure environment as complementary.$^{98}$ EUFOR Althea personnel contributed to disrupting crime through vehicle checks and similar interventions but this brought criticism from the parallel EU Police Mission. ${ }^{99}$ EUPM considered EUFOR involvement an unwelcome interference in policing responsibilities. ${ }^{100}$ Eva Gross also noted concerns over coherence between different actors. ${ }^{101}$ The EU Special Representative in Sarajevo and the PSC adjusted the overlapping competences of the missions, giving EUPM the lead in fighting crime, in capacity building and institutional development in support of the local police. EU instruments in $\mathrm{BiH}$ had inherited roles from previous UN interests: EUPM replaced the International Police Task Force (IPTF), Althea followed NATO's SFOR, while the EUSR is an extension of the UNHR, so all three instruments lacked full EU identity and purpose. ${ }^{102}$ Despite the EUPM closing in 2012, there still remains public suspicion of law enforcement agencies in $\mathrm{BiH}$ and little confidence in police competence or trustworthiness. ${ }^{103}$

A vital context to EUFOR Althea it operates in a post-conflict society where internal security risks endure, albeit on a reduced scale. While the quantity of weapons in the country has diminished, Bertin described a 'weak economy (with) widespread organised crime and corruption and the fragility of the rule of law (...) deeply divided along ethnic lines and across the two entities (...) the Bosniak/Croat Federation and Republika Srpska., ${ }^{104}$

This assessment holds true a decade later. Althea's long-term, strategic task is 'to leave behind a peaceful and stable Bosnia en route towards EU membership.' ${ }^{105}$ The 2014 elections echoed the downbeat assessments reported above as they reflected the ethnic divisions institutionalised by the DPA. ${ }^{106}$ The most immediate threat to the integrity of the state is the apparent determination of the Republika Srpska leadership to further promote nationalist sentiment and undermine the federal institutions and judicial authorities. The

\footnotetext{
96 WBIF 2014, 11.

97 Boštjančič Pulko et al. 2016.

98 Klein 2010, 150.

99 EUPM BiH n.d.

100 Merlingen and Ostrauskaité 2006.

101 Gross 2007.

102 Dziewulska 2011.

103 Boštjančič Pulko et al. 2016.

104 Bertin 2008, 61-2.

105 Ibid., 76.
}

106 New York Times 2014; Biermann 2014. 
UN High Representative Valentin Inzko reported in 2015 that while BiH had been 'a shining star in peacebuilding and reintegration' during the first ten years after Dayton, the next ten years had shown an alarming level of dysfunction. State integrity is undermined by Republika Srpska holding a referendum in September 2016 on the right to have a national holiday and threatening another on the status of the $\mathrm{BiH}$ federal institutions. ${ }^{107}$ Inzko criticised the 2016 referendum as a flagrant defiance of the Dayton-Paris Accords and federal state constitutional provisions. He expressed regret at gains made by nationalist candidates in elections in October. At the same time, the RS national assembly chose to decorate several convicted war criminals, including Radovan Karadžić. ${ }^{108}$ While Bosnia is stuck in a political quagmire, the economy also remains in a parlous state. ${ }^{109}$

The EUFOR Althea mandate reflects a subtle shift in the focus of the operation. Now instead of the main thrust being to uphold the Dayton Peace Accords, the emphasis is on a safe and secure environment and capacity building and training (CB\&T) for the federal armed forces (AFBiH). This complements the multinational battalion (MNBN) established since 2007, able to act autonomously or in support of the $\mathrm{BiH}$ authorities or international community agencies in theatre as requested. The third area of operations is Liaison and Observations Teams distributed throughout the territory as 'eyes and ears' able to communicate situational reports to EUFOR HQ in Butmir, Sarajevo. ${ }^{110}$

Given the weakness of the federal institutions, what conclusions can be drawn about the implementation of Althea? This research suggests that the mission delivers improvements, but fundamental challenges regarding the integrity of the state are not adequately addressed. Althea depends on agreement and compromise among 28 member states. Chronic resource inadequacies remain as personnel reductions have not been mirrored by fundamental improvements in governance, or socio-economic prospects. Althea faces formidable challenges, well beyond the UN-provided remit. If a fundamental problem is that the DPA consolidates ethnic cleansing and has not delivered consensus on state structures, this is not an issue for EUFOR Althea. If the entities comprising the state cannot cohere around the federal institutions, this is a matter for the wider international community as well as for Bosnia and Herzegovina itself. Clearly the EU has a huge stake in the future stability and security of $\mathrm{BiH}$, but the challenges involved extend beyond the remit and capabilities of EUFOR Althea. Despite deficiencies, the operation retains the strong local support and its capacity building and training of the AFBiH helps to establish a safe and secure environment (SASE), especially as Althea seeks to transfer this responsibility to $\mathrm{BiH}$ itself, consistent with the EU principle of 'local ownership.'111

107 United Nations 2015.

108 United Nations 2016.

109 European Commission 2014, 2015b, 2016; Heritage Foundation 2018.

110 EUFOR Althea, 2018.

111 Ejdus 2018; Donais 2008; EU 2008. 
EUFOR Althea's achievements have proceeded in a piecemeal and incremental fashion, typical of 'muddling through. ${ }^{12}$ Nevertheless, the mission itself reports declining public confidence in the security situation. ${ }^{113} \mathrm{~A}$ long-held criticism of the EU is that it is remote, lacking proper engagement with the issues facing Bosnia (Interviews 15-17,19,21). This reflects the lack of political will among member states. But CSDP lies within CFSP, an intergovernmental field. There have been significant institutional developments, namely increased Commission involvement, EEAS consolidation, and engaged, proactive leadership from the HRVP. This position provides important bridging between the Commission and Council, while the CMPD, answerable to the PSC, has improved mission coordination.

\section{Bureaucratic Politics, Emergent Strategy?}

Grand Strategy presupposes strategic goals backed by adequate resourcing and actorness. A tension exists between Grand Strategy and bureaucratic politics given the fundamentally bureaucratic nature of EU policy-making and implementation processes, as well as the failure of intergovernmentalism, to deliver a strategic EU security and defence policy. While bureaucracy is what modern society and modern states depend upon, bureaucratic politics is the process through which CSDP governance operates.

EUFOR Althea is an example of CSDP working through bureaucratic politics where suboptimal outcomes are the norm and missions are governed by a hierarchical technocracy that answers to member states through the Council and its proxies, especially the PSC. CSDP demonstrates limited legitimacy through a low level of public consent and minimal parliamentary scrutiny. CSDP is run by a complex network of committees staffed by technocratic experts and officials appointed by member states and other EU organisations. Outcomes are low-level and under-reported, making scrutiny difficult; they reflect 'satisficing' rather than strategic gains. ${ }^{114}$ Compromise and consensus are goals of the policy-making process, rather than defending principles. A DGAP expert (Interview 25) describes CSDP as a 'technocratic community' rather than a political one, while another (Interview 23) describes an EEAS 'technocratic culture.'

Member states have regarded $\mathrm{BiH}$ as relatively low-risk. They assume that renewed intercommunal violence is unlikely, even as Althea itself and the UNHR for BiH report a deteriorating political and security environment. Althea has not been a priority interest. It has depended on lowest-common-denominator agreement; it has lacked clearly defined targets, or measurable outcomes, its success remains hard to measure. The short tenure of officials, whether posted directly to the mission, or as member state appointees to the EEAS/security arena in Brussels, also suggests a 'muddling through' approach relying on horizontal networks to meet minimal organisational goals.

112 Lindblom 1959, 83.

113 EUFOR Althea 2017.

114 Allison and Zelikow 1999, 152. 
Given this context, can there be a strategic dimension to the mission, perhaps reflecting CSDP as a whole? The EU's wider Balkans policy does suggest a strategic - and comprehensive - approach, but weak member state commitment undermines the potential for positive outcomes, particularly in a short timeframe. At best this is an emergent strategy, rooted in gradualism and minimalism. CSDP implementation in BiH suggests a strategy of sorts, but hardly a Grand Strategy.

In management studies literature there is a link between bureaucracy and emergent strategy. This fits with the bureaucratic politics of CSDP. The European Union, member states and the Commission especially rely on a gradualist, incremental and low-cost approach to transformation in the Balkans. This is especially difficult in Bosnia (and Kosovo) where chronic political dysfunction and sectarian division persists. The 'frozen conflict' remains, and Republika Srpska has little interest in the survival of the federal state. Ethnic tensions remain within and between the entities and ethnicities comprising the federal state.

According to Mintzberg, the contemporary organisation works as a system characterized by formal authority, regulated flows, informal communication, work constellations, and ad hoc decision processes. ${ }^{115}$ There are parallels with the hierarchical and technocratic processes of bureaucratic politics in this description. Organisations function in complex and varying ways due to differing flows, including flows of authority, work material, information, and decision processes. ${ }^{116}$ Strategy emerges from multiple processes, ${ }^{117}$ including disjointed incrementalism, ${ }^{118}$ lessons learned, entrepreneurial factors relating to vision and leadership, and power dynamics comprising both micro-power within organisations and macro-power.

This correlates well with CSDP post-Lisbon, where intergovernmental power interacts with policy-making networks in the multilevel and heterarchical system of EU foreign and security policy. ${ }^{119}$ Freedman confirms the importance of lessons learned in a complex and changing environment, where a linear top-down imposed strategy is unlikely to work. ${ }^{120}$ Instead a form of 'emergent strategy' that takes account of complexity and changing circumstances, multiple channels of influence and complex decision-making networks is more likely to succeed. A senior EDA official (Interview 7) highlights coordination and chain-of-command difficulties, echoing Asseburg and Kempin who report a lessons-learned process in CSDP as 'woefully absent' especially in the civil sphere. ${ }^{121}$ Bossong similarly criticises the informal and haphazard way in which experience informs

115 Mintzberg 1979; Mintzberg and McHugh 1985.

116 Mintzberg 1978, 1979; Mintzberg and Waters 1985.

117 Mintzberg and Lampel 1999.

118 Lindblom 1959.

119 Mérand et al. 2011.

120 Freedman 2013, 555.

121 Asseburg and Kempin 2009, 154. 
a learning process, while also estimating that the EEAS will bring more effective tracking of experience which should improve mission effectiveness. ${ }^{122}$ It is surprising that the recommendations in the EEAS Review do not include the introduction of a proper lessonslearned approach. ${ }^{123}$ This is fertile ground for more research to better understand the processes through which CSDP can benefit from emergent strategy. It also connects with the notion of an emergent EU strategic culture. ${ }^{124}$

Mintzberg and Lampel refer to an emergent strategy that uses social processes and cultural factors, ${ }^{125}$ a constructivist dimension which recalls Brusselisation. ${ }^{126}$ In a development of Mintzberg's notion of emergent strategy, Chia and Holt consider rational, deliberate and designed strategy as naive, given the existence of too many contingencies and alternative limits, and too many system influences. Instead they point to 'the surprising efficacy of indirect action. ${ }^{\prime 27}$ This chimes with the ascendancy of bureaucratic politics where much is indirect, and where even 'confusion between (...) officials' may contribute to policy outcomes. ${ }^{128}$ The following description of a type of bureaucracy appears to match the dominant characteristics of CSDP: 'A system of representative government requires officials to act as the custodians of the constitutional values it embodies (so) it cannot frame the role of bureaucrats solely in terms of efficient management, performance, responsiveness and securing results. ${ }^{129}$

In other words, bureaucracies are not predictable: they display characteristics other than efficient management with measurable results. The EU is a system of representative government, a democratic type, and a bureaucracy. It purports to uphold values that are core to its evolving strategic culture, but the manner in which it pursues its ambition reflects bureaucratic politics, where values may be shared but efficiency or even effectiveness cannot be guaranteed, or even satisfactorily measured. Broadly expressed values, for so long underpinning the construction of a social Europe, have been shaken by the neoliberal ascendancy since the 2004 enlargement, and by deep divisions between member states on how to deal with the problems of Economic and Monetary Union, the travails of the single currency, and mass migration provoked by wars and state failure in MENA and beyond.

122 Bossong 2013.

123 EEAS 2013a.

124. Biava et al. 2011.

125 Mintzberg and Lampel 1999.

126 Allen 1998; Mérand 2008.

127 Chia and Holt 2009, 203.

128 Allison 1969, 708.

129 du Gay 2000, 12. 


\section{Conclusion}

The comprehensive approach incorporates security with political and economic development, and uses a wide range of instruments to pursue different but linked objectives. CSDP in the Western Balkans reflects this while it also revealing an emergent strategy. This article has focused on EUFOR Althea, highlighting deep seated problems that the mission faces in Bosnia and Herzegovina, probably - together with Kosovo - the most challenging in the region. The $\mathrm{EU}$ approach to the Western Balkans constitutes a strategic endeavour that proceeds incrementally, with modest progress on various fronts. Processes of bureaucratic politics have enabled an emergent strategy precisely because, as with Brusselsisation, there has been no power transfer, avoiding the failure that Grand Strategy would arguably have encountered, given the near certainty that Member States would have resisted supranational institution building in the defence and security arena, preferring instead to protect the intergovernmentalism that has underpinned common foreign and security policy since Maastricht.

EU instruments, including EUFOR Althea, the EUSR and the EUD in Sarajevo, and Commission engagement through the SAA, have undoubtedly helped to stabilise Bosnia and Herzegovina. But a deteriorating situation now requires a stronger military presence. ${ }^{130}$ So, while EUFOR Althea can be said to have 'civilianised', relying on NATO to preserve regional peace is not sustainable. Much the same can be said of the entire Common Security and Defence Policy: it needs military credibility.

Here and elsewhere I have argued that traditional intergovernmentalism has proven unable to deliver on the promise of common security and defence. ${ }^{131}$ Grand Strategy has proven elusive due to significant non-cooperation, outright opposition, or free-riding by various member states. Instead progress has been achieved through bureaucratic politics which has facilitated a process of emergent strategy throughout the Western Balkans. We are probably at the limit of what this gradualist and incremental process can achieve, it being overly reliant on a Brussels-based technocracy. Contemporary threats and turbulence in the international environment and even in the Union itself - such as the UK's presumed departure (Brexit) - can spur determination to achieve common security and defence through the overdue activation of Permanent Structured Cooperation (PESCO). ${ }^{132}$ The technocratic processes of the open method of coordination (OMC) can also play a key role in building common policy and capability in this area. ${ }^{133}$ Together with PESCO, through which groups of Member States cooperate in security and defence while others remain semi-detached or outside the initiative, this may finally bring the Union towards a coherent and even an integrated common security and defence arrangement. In an increasingly unstable environment, this looks essential for the peace and stability of the EU and its environment. The UK too, Brexit or No Brexit, should be fully integrated in this endeavour.

130 Arbeiter and Udovič 2016.

131 Sweeney and Winn 2017.

132 European Council 2017a, 2017b, 2017c; EEAS 2018; Biscop, 2017.

133 Sweeney and Winn 2017. 


\section{Appendix: Interviews}

1 Security and defence policy expert, ISIS, Paris 16/06/2010

2 Expert on EU Common Foreign and Security Policy, Brussels 17/06/2010

3 European foreign and security policy expert, Leeds 25/06/2010

4 Security and defence policy expert, Brussels 01/07/2010

5 Former military officer and ESDP expert, Brussels 08/09/2010

6 Expert on Civilian Aspects of Crisis Management, Brussels, 09/09/2010

7 Senior Official in EDA, Brussels 10/09/2010

8 Official in EU Military Staff in Council Secretariat, Brussels, 22/09/2010

9 Military official in CMPD, Brussels, 24/09/2010

10 Security and defence expert in ECFR, London 30/09/2010

11 EU Foreign policy expert, York, 18/11/2010

12 Senior Official in MoD, London 10/03/2011

13 Military representative inside EEAS, Brussels 23/03/2011

14 Former Member of Venusberg Group, Munich 25/03/2011 (telephone)

15-21 EUFOR ALTHEA Sarajevo interviews

15 Consultant to EUFOR Althea, 16/05/2011

16 Senior Official in OHR, 17/05/2011

17 Chief of Political Dept in OHR, 17/05/2011

18 Senior Official in EUFOR HQ, 18/05/2011

19 Senior Official (2) in EUFOR HQ, 18/05/2011

20 Consultant to project for EU Delegation/European Commission, 19/05/2011 
21 Senior Policy Adviser to EUSR/EUFOR, 25/05/2011 (telephone)

22 Defence and security expert, Stiftung Wissenshaft und Politik, Berlin 27/09/2011

23 Defence and security expert, German Council on Foreign Relations (DGAP), Berlin. 27/09/2011

24 SPD Member of Bundestag in the Grand Coalition 2002-06, 09/07/2012

25 Defence and security expert, DGAP, Berlin11/07/2012

26 Senior Official in the European Parliament, 10/05/2013

27 Expert on Kosovo and EULEX KOSOVO, Leeds, 18/07/2013

28 Senior Brussels-based journalist and EU expert (various dates) 


\section{References}

Adler, Emanuel, and Haas, Peter. 1992."Conclusion: epistemic communities, world order, and the creation of a reflective research program". International Organization 46(1): 367-390.

Allen, David. 1998."Who speaks for Europe? The search for an effective and coherent external policy". In A Common Foreign Policy for Europe? Edited by John Peterson and Helen Sjursen, 41-58. London: Routledge.

Allison, Graham. 1969.“Conceptual Models and the Cuban Missile Crisis”. American Political Science Review 63(3): 689-718.

1971.Essence of Decision. Boston: Little Brown.

Allison, Graham, and Zelikow, Philip. 1999.Essence of Decision: Explaining the Cuban Missile Crisis. New York and Harlow: Longman.

Arbeiter, Jana, and Boštjan Udovič. 2016.'The International Community and the European Community in the Western Balkans: from 'Disinterest' to 'Active Participation"'. European Perspectives 8 (2): 41-62.

Ashton, Catherine. 2013.“HR/VP Statement on EEAS Review”. SPEECH/13/530, 12 June.

Asseburg, Muriel, and Ronja Kempin, eds. 2009.“The EU as a strategic actor in the realm of Security and Defence?" SWP Policy Paper. Berlin: Stiftung Wissenshaft und Politik.

Barnett, Michael, and Martha Finnemore. 1999““The Politics, Power, and Pathologies of International Organizations". International Organization 53(4): 699-732.

BBC News. 2013.“Cameron rejects French claims of 'phoney' defence row”. 20 December. Accessed June 06, 2018.http://www.bbc.co.uk/news/ukpolitics-25463680.

Beetham, David. 1987. Bureaucracy. Milton Keynes: Open University Press.

Berg, Patrick. 2009. "EUFOR Tchad/RCA" in The EU as a strategic actor in the realm of Security and Defence? Edited by Muriel Asseburg and Ronja Kempin, 57-69. Berlin: Stiftung Wissenshaft und Politik.

Bertin, Thomas. 2008“'The EU Military Operation in Bosnia”. In European Security and Defence Policy: An implementation Perspective. Edited by Michael Merlingen and Rasa Ostrauskaité. London: Routledge. 
Biava, Alessia, Margriet Drent and Graeme Herd. 2011."Characterizing the European Union's Strategic Culture: An analytical framework". Journal of Common Market Studies 49(6): 1227-1248.

Bickerton, Christopher. 2011.“Towards a Social Theory of EU Foreign and Security Policy". Journal of Common Market Studies 49(1): 171-190.

-.-.-- 2013.European Integration: from Nation States to Member States. Oxford: Oxford University Press.

Biermann, Rafael. 2014."Coercive Europeanization: the EU's struggle to contain secessionism in the Balkans". European Security 23(4): 484-508.

Biscop, Sven, ed. 2009“'The Value of Power, the Power of Values: A Call for an EU Grand Strategy". Egmont Paper 33. Brussels: Egmont Institute.

-..- 2011.'A New External Action Service Needs a New European Security Strategy". Security Policy Brief29, November. Brussels: Egmont Institute.

2013.“The European Security Strategy: Towards a grand strategy?” in Routledge Handbook of European Security, edited by Sven Biscop and Richard Whitman, 38-49. London: Routledge.

-...- 2015. "Global and Operational: A New Strategy for EU foreign and security policy”. IAI Working Papers, July, 15-27. Rome: Istituto Affari Internazionali.

2016. "The EU Global Strategy: Realpolitik with European Characteristics". Security Policy Brief, 75. Brussels: Egmont Institute.

2017. "European Defence: What's in the CARDs for PESCO?”. Security Policy Brief91. Brussels: Egmont Institute.

Bisco, Sven, and Jo Clermont. 2010a. “A Strategy for CSDP: Europe’s Ambitions as a Global Security Provider”. Egmont Paper 37. Brussels: Egmont Institute.

2010b. "Permanent Structured Cooperation in Defence: Building Effective European Armed Forces”. Bruges Political Research Papers 15, September. Brugger: College of Europe.

-...- 2011. "CSDP and the Ghent Framework”. European Foreign Affairs Review $16: 149-167$.

2012. Europe, Strategy and Armed Forces: The Making of a Distinctive Power. London: Routledge/Cass Military Studies. 
2013b. "Military CSDP: The Quest for Capability." In Routledge Handbook of European Security, edited by Sven Biscop and Richard Whitman, 78-90. London: Routledge.

Biscop, Sven, and Richard Whitman.2013. "Introduction" in Routledge Handbook of European Security, edited by Sven Biscop and Richard Whitman,1-2. London: Routledge.

Blockmans, Steven, and Ramses Wessel.2009. "The European Union and Crisis Management: Will the Lisbon Treaty Make the EU More Effective?". Conflict and Security Law 14(2): 265-308.

Bossong, Raphael. 2013."EU Civilian crisis management and organizational learning”. European Security 22(1): 94-112.

Bossong, Raphael, and Thorsten Benner. 2010."The Case for a Public Administration Turn in the study of the EU's Civilian Crisis Management." Journal of European Public Policy 17(7): 1074-1086.

Boštjančič Pulko, Ivana, Meliha Muherina and Nina Pejič. 2016."Analysing the Effectiveness of EUFOR Althea Operation in Bosnia and Herzegovina”. European Perspectives 8(2), October.

Capussela, Andrea. 2015a."Eulex report exposes EU failure in Kosovo”. EUObserver, 16 April.

-.--- 2015b. State-building in Kosovo: Democracy, Corruption and the EU in the Balkans. London: IB Tauris.

Chappell, Laura. 2012. Germany, Poland and the Common Security and Defence Policy: Converging Security and Defence Perspectives in an Enlarged EU. Basingstoke: Palgrave Macmillan.

Chappell, Laura, and Petar Petrov. 2014."The European Union's Crisis Management Operations: Strategic Culture in Action?". European Integration On-line Papers 18(2): $1-24$.

Chia, Robert, and Robin Holt. 2009. Strategy Without Design: the Silent Efficacy of Indirect Action. Cambridge: Cambridge University Press.

Council of the European Union. 2010. Press Release. Foreign Affairs Defence and Development. Presse 342 PR CO 46. 9 December. 
Cross, Mai'a. 2011. Security integration in Europe: How knowledge-based networks are transforming the European Union. Michigan: University of Michigan Press.

Crowe, Brian. 2008. The European External Action Service: Roadmap for Success. London: RIIA.

Dijkstra, Hylke. 2009. "Commission Versus Council Secretariat: An Analysis of Bureaucratic Rivalry in European Foreign Policy”. European Foreign Affairs Review 14(3): 431-450.

2011. "The Political Influence of the EU Council Secretariat in Security and Defence Policy”. Paper delivered at European Union Studies Association Biennial Conference Boston 3-5 March.

-...- 2012a. "The Influence of EU Officials in European Security and Defence". European Security 21(3): 311-327.

2012b. "Agenda-setting in the Common Security and Defence Policy: An institutionalist perspective". Cooperation and Conflict 47(4): 454-472.

2016. "Introduction: One-and-a-Half Cheers for the EU Global Strategy". Contemporary Security Policy, 37(3): 369-373.

Di Mauro, Danilo, Ulrich Krotz, and Katerina Wright, eds. 2017.EU's Global Engagement: a Database of CSDP Military Operations and Civilian Missions Worldwide. Florence: European University Institute.

Dinan, Desmond. 2011. "Governance and Institutions: Implementing the Lisbon Treaty in the Shadow of the Euro Crisis". Journal of Common Market Studies 49, Annual Review: 103-121.

Donais, Timothy, ed. 2008. Local Ownership and Security Sector Reform. Geneva: DCAF.

du Gay, Paul. 2000. In Praise of Bureaucracy: Weber, Organization, Ethics. London: Sage.

Dziewulska, Agata. 2011.'An Impossible Pasodoble: EU and Bosnia Today”. Yearbook of Polish European Studies 13: 174-184.

EEAS. 2013a. EEAS Review Brussels: European External Action Service.

-...-- 2013b. "Serbia and Kosovo reach landmark deal”. 19 April. Accessed 06 June 2018. http://www.eeas.europa.eu/top_stories/2013/190413_eu-facilitated_dialogue_ en.htm 
2014.EUFOR Althea. Factsheet. April. Brussels: European External Action Service. Accessed 6 June 2018. http://eeas.europa.eu/csdp/missions-and-operations/ althea-bih/pdf/factsheet_eufor_althea_en.pdf.

2018. Permanent Structured Cooperation (PESCO) Factsheet,5 March. Accessed 6 June 2018.https://eeas.europa.eu/headquarters/headquarters-homepage_ en/34226/Permanent\%20Structured\%20Cooperation\%20(PESCO)\%20-\%20Factsheet.

Ejdus, Filip. 2018. '"Here is your mission, now own it!' The rhetoric and practice of local ownership in EU interventions." European Security 26 (4): 461-484.

Emerson, Michael and Eva Gross. 2007."Introduction.” In Evaluating the EU's Crisis Missions in the Balkans, edited by Michael Emerson and Eva Gross, 1-16. Brussels: Centre for European Policy Studies.

EU. 2008. Security sector reform - Draft document on deployable European expert teams, October 21. 14576/1/08 REV 1.

EU Delegation BiH. 2017.Council conclusions on Bosnia and Herzegovina, 16 October 2017. Accessed 6 June 2018. http://europa.ba/?p=52905.

EUFOR Althea. 2018. Mission website. Brussels: EEAS. Accessed 6 June 2018. http:// www.euforbih.org/.

2017. “Operation Althea European Union Force in BiH”. Information Booklet. December. Sarajevo: EUFOR Althea. Accessed 6 June 2018.http://www.euforbih.org/ eufor/images/pdfs/EUFOR_ALTHEA_Information_Booklet_Dec_2017.pdf.

EUPM BiH. n.d. Mission website. Brussels: EEAS. Accessed 6 June 2018.http://www. eeas.europa.eu/csdp/missions-and-operations/eupm-bih/index_en.htm.

EurActiv. 2015."Poverty spurs mass migration from Kosovo," 16 February. Accessed 6 June 2018.http://www.euractiv.com/sections/global-europe/poverty-spurs-massmigration-kosovo-312131.

European Commission. 2014. "Bosnia and Herzegovina Progress Report." Brussels: European Commission. Accessed 6 June 2018. http://ec.europa.eu/enlargement/pdf/ key_documents/2014/20141008-bosnia-and-herzegovina-progress-report_en.pdf.

2015a. "Press Release: Stabilisation and Association Agreement with Bosnia and Herzegovina enters into force today," 1July. Accessed 6 June 2018. http://europa. eu/rapid/press-release_IP-15-5086_en.htm. 
-2015b. “Commission Staff Working Document: Kosovo 2015 Report,"11 November. Accessed 11 February 2016. http://ec.europa.eu/enlargement/pdf/key_ documents/2015/20151110_report_kosovo.pdf.

2015c. "Commission Staff Working Document: Bosnia and Herzegovina 2015 Report,"10 November. Accessed 11 February 2016. http://ec.europa.eu/enlargement/ pdf/key_documents/2015/20151110_report_bosnia_and_herzegovina.pdf

2016. Bosnia and Herzegovina 2016 Report. Accessed 26 February 2017. http://www.un.org/press/en/2015/sc12114.doc.htm.

European Council. 1999a. Cologne European Council, 3-4 June. Presidency Conclusions. Accessed 5 March 2015.http://www.europarl.europa.eu/summits/ kol1_en.htm.

1999b. Helsinki European Council, 10-11 December. Presidency Conclusions. Accessed 5 March 2015. http://www.europarl.europa.eu/summits/ hel1_en.htm.

2008. 'Report on the Implementation of the European Security Strategy: Providing Security in a Changing World' European Council. 11 December. Accessed 17 July 2015. http://www.consilium.europa.eu/ueDocs/cms_Data/docs/pressdata/ EN/reports/104630.pdf.

-.-.-. 2010. Council Conclusions on Bosnia Herzegovina: EUFOR Althea. Foreign Affairs Council Meeting. 25 January.

2013. Council Conclusions EUCO 217/13 19/20 December. Accessed 19 January 2015. http://www.consilium.europa.eu/uedocs/cms_data/docs/pressdata/en/ ec/140214.pdf.

2015. Council Conclusions EUCO 22/15. Accessed 26 June 2015.

2017a. 'Defence cooperation: Council establishes Permanent Structured Cooperation (PESCO), with 25 member states participating. Press Release December 11. Brussels: European Council. Accessed 20 December 2017. http://www.consilium. europa.eu/en/press/press-releases/2017/12/11/defence-cooperation-pesco25member-states-participating/\#.

2017b. 'Security and defence: Council reviews progress and agrees to improve support for military missions' Press release. Brussels: European Council. Accessed 20 December 2017. http://www.consilium.europa.eu/en/press/pressreleases/2017/03/06-defence-security/. 
2017c. Council conclusions on progress in implementing the EU Global Strategy in the area of Security and Defence Press release. Brussels: European Council. Accessed 20 December 2017. http://www.consilium.europa.eu/en/press/ press-releases/2017/03/06-conclusionssecurity-defence/.

European Parliament. 2016a. "Briefing: How the EU budget is spent”. March 16. Brussels: European Parliament. Accessed 7 June 2018. http://www.europarl.europa. eu/RegData/etudes/BRIE/2016/579065/EPRS_BRI\%282016\%29579065_EN.pdf.

2016b. "Financing of CSDP missions and operations". At a Glance. February. Brussels: European Parliament. Accessed 7 June 2018. http://www.europarl.europa. eu/RegData/etudes/ATAG/2016/577958/EPRS_ATA(2016)577958_EN.pdf.

Feaver, Peter. 2009."What is grand strategy and why do we need it?" Shadow Government Blog. Foreign Policy. 8 April. Accessed 7 June 2018.http://shadow. foreignpolicy.com/posts/2009/04/08/what_is_grand_strategy_and_why_do_we_ need_it

Freedman, Lawrence. 2013. Strategy: A History. Oxford: Oxford University Press.

Gaddis, John. 2009.“What is grand strategy?” Karl Von der Haden Distinguished Lecture, Duke.

Giddens, Anthony. 1971. Capitalism and Modern Social Theory Cambridge: Cambridge University Press.

Grässle, Ingeborg. 2011. "The Creation of the European External Action Service: A Critical Analysis”. European Issue 194 (14), February. Brussels: Robert Schumann Foundation.

Grevi, Giovanni, Damien Helly, and Daniel Keohane,eds.2009.European Security and Defence Policy: The first ten years (1999-2009). Paris: The European Union Institute for Security Studies.

Gross, Eva. 2007. "Civilian and military missions in the Western Balkans”. In Evaluating the EU's Crisis Missions in the Balkans, edited by Michael Emerson and Eva Gross, 115-137. Brussels: Centre for European Policy Studies.

2015. "Bosnia and Herzegovina: Back on an EU track?” Alert 19. March. Paris: IISS.

Gross, Eva, and Alessandro Rotta. 2011“"The EEAS and the Western Balkans"IAI Working Papers 11-15 June. Rome: Istituto Affari Internazionali. 
Guardian. 2018a. "Arms shipment to Bosnian Serbs stokes EU fears". London: Guardian Newspapers Ltd. 13 February. Accessed 7 June 2018. https://www. theguardian.com/world/2018/feb/13/bosnian-serb-police-arms-purchase-stokes-eufears Accessed 24/02/2018.

-...-...- 2018b. "Russian-trained mercenaries back Bosnia's Serb separatists”. London: Guardian Newspapers Limited. 12 January. Accessed 7 June 2018. https:// www.theguardian.com/world/2018/jan/12/russian-trained-mercenaries-backbosnias-serb-separatists.

Hadfield, Amelia, and Daniel Fiott. 2013."Europe and the Rest of the World." Journal of Common Market Studies 51 (Annual Review): 168-182.

2014. "Relations with the Rest of the World: From Chaos to Consolidation?" Journal of Common Market Studies 52(S1): 170-185.

Haine, Jean-Yves. 2008. "Battle Groups: out of necessity, still a virtue?". European Security Review 39: 1-5.

Hansard. 2008. Presidency Report on European Security and Defence Policy. 8 January.

Hartlapp, Miriam, Julia Metz, and Christian Rauh. 2013. "Linking Agenda Setting to Coordination Structures: Bureaucratic Politics inside the European Commission". Journal of European Integration 35(4): 425-441.

Heidenreich, Martin, and Jonathan Zeitlin, eds.2009.Changing European and Welfare Regimes: The Influence of the open method of coordination. London, New York: Routledge.

Helly, Damien. 2016."Mogherini's new Global Strategy Offers Lighthouse for EU in Uncertain Waters”. EurActiv, 1 July. Accessed 7 June 2018. http://eurac.tv/2APx.

Helwig, Niels. 2013. "EU Foreign Policy and the High Representative's CapabilityExpectations Gap: A Question of Political Will”. European Foreign Policy Review 18(2): $235-254$.

Heritage Foundation. 2018. "2015 Index of Economic Freedom: Bosnia and Herzegovina”. Accessed 7 June 2018.http://www.heritage.org/index/country/ bosniaherzegovina

HM Government. 2017a. "PM: Britain is unconditionally committed to the defence and security of Europe" Press Release 28 September. London: HM Government. 
Accessed 7 June 2018.https://www.gov.uk/government/news/pm-britain-isunconditionally-committed-to-the-defence-and-security-of-europe.

2017b. "Defence Minister reaffirms UK commitment to European security". News story, 13 November. Accessed 7 June 2018. https://www.gov.uk/government/ news/defence-minister-reaffirms-uk-commitment-to-european-security.

Howorth, Jolyon. 2010. “The EU as a Global Actor: Grand Strategy for a Grand Global Bargain?”. Journal of Common Market Studies 48(3): 455-474.

2013. "European Security Institutions 1945-2010: The weaknesses and the strengths of 'Brusselsisation". In Routledge Handbook of European Security, edited by Sven Biscop, and Richard Whitman, 5-17. London: Routledge.

Irish Times. 2017. "Serbia seeks more arms and energy from Russia despite Western Qualms". 19 December. Accessed 7 June 2018. https://www.irishtimes.com/news/ world/europe/serbia-seeks-more-arms-and-energy-from-russia-despite-westernqualms-1.3332985.

Jaqué, Jean-Paul. 2015. “Review of the EULEX Kosovo Mission's Implementation of the Mandate with a particular focus on the Handling of the Recent Allegations". 31 March. Brussels: European Commission.

Kaldor, Mary. 2007. Human Security. Cambridge: Polity Press.

-..-- 2012. "The EU as a New Form of Political Authority: The Example of the Common Security and Defence Policy". Global Policy 3(1): 79-86.

Kanninen, Tapio, and Touko Piiparinen. 2014. "Why bureaucracies matter in the global age: A post-Weberian explanation with the Case Study of preparing and implementing the United Nations". Agenda for Peace' International Relations 28(1): 46-66.

Kaunert, Christian, and Sarah Léonard. 2012. "Introduction: Supranational Governance and European Union Security after the Lisbon Treaty - Exogneous shocks, policy entrepreneurs and 11 September 2001". Cooperation and Conflict 47(4): 454-472.

Keohane, Daniel. 2009. "EUFOR ALTHEA (Bosnia and Herzegovina): The European Union military operation in Bosnia and Herzegovina”. In European Security and defence Policy: The first ten years (1999-2009), edited by Giovanni Grevi, Damien Helly, and Daniel Keohane. Paris: The European Union Institute for Security Studies. 
Kirchner, Emil. 2013. "Common Security and Defence Policy peace operations in the Western Balkans: impact and lessons learned”. European Security 22(1): 36-54.

Klein, Nadia. 2010. European Agents out of Control? Delegation and agency in the Civil-Military Crisis Management of the European Union. Baden Baden. Nomos Verlagsgesellschaft.

Knezevic, Gordana. 2018. "Talk of Paramilitaries, Real or Imagined, could fuel division”. Balkans without Borders 21 February. Accessed 7 June 2018. https://www. rferl.org/a/balkans-talk-of-paramilitaries-fuel-division/29055292.html.

Lindblom, Charles. 1959. “The Science of 'Muddling Through". Public Administration Review 19(2): 79-88.

Lindstrom, Gustav. 2007. "Enter the EU Battlegroups". Chaillot Papers 97. March. Paris: Institute for Security Studies.

- 2011. “EU Battlegroups: Options for the Future?". Studia Diplomatica 64(1): 29-40.

McMahon, Patrice, and Jon Western. 2009. “The Death of Dayton: How to Stop Bosnia from Falling Apart”. Foreign Affairs. September/October Edition. Tampa (FL): Council on Foreign Relations. Accessed 7 June 2018. http://www.foreignaffairs.com/ articles/65352/patrice-c-mcmahon-and-jon-western/the-death-of-dayton.

Mälksoo, Maria. 2016. "From the ESS to the EU Global Strategy: External Policy, Internal Purpose". Contemporary Security Policy37(3):374-388.

Manners, Ian. 2002. "Normative Power Europe: a contradiction in terms?". Journal of Common Market Studies 40(2): 234-58.

Martin, Garret. 2013. “The European External Action Service Comes of Age: An Assessment”. European Affairs, December. Washington: The European Institute.

Accessed 7 June 2018. http://www.europeaninstitute.org/index.php/190-europeanaffairs/ea-december-2013/1826-the-european-external-action-service-comes-of-agean-assessment.

Mattelaer, Alexander. 2013.The Politico-Military Dynamics of European Crisis Response Operations: Planning, Friction, Strategy. Basingstoke: Palgrave Macmillan.

Mauri, Filippo and Gya, Giji. 2009."The Setting Up of the European External Action Service (EEAS): Laying the Basis for a More Coherent European Foreign Policy?"European Security Review 47: 4-10. 
Menon, Anand. 2009.“Empowering Paradise: ESDP at Ten”. International Affairs 85(2): 227-246.

Mérand, François. 2008.European Defence Policy: Beyond the Nation State. Oxford: Oxford University Press.

Mérand, François, Stephanie Hofmann, and Bastien Irondelle. 2011.“Governance and State Power: A Network Analysis of European Security”. Journal of Common Market Studies 49(1): 121-147.

Merlingen, Michael. 2013. "The CSDP in the Western Balkans: From experimental pilot to security governance". In Routledge Handbook of European Security, edited by Sven Biscop and Richard Whitman, 145-158. London: Routledge.

Merlingen, Michael, and Rasa Ostrauskaité. 2006.European Union Peacebuilding and Policing. London: Routledge.

Mintzberg, Henry. 1978. "Patterns in Strategy Formation”. Management Science 24(9): 934-948.

1979.The Structuring of Organizations: A Synthesis of the Research. Chicago: University of Illinois.

Mintzberg, Henry, and Joseph Lampel. 1999."Reflecting on the Strategy Process". Management Review Boston: MIT Sloan. Accessed 8 June 2018.http://sloanreview. mit.edu/article/reflecting-on-the-strategy-process/.

Mintzberg, Henry, and Alexandra McHugh. 1985.'Strategy Formation in an Adhocracy”. Administrative Science Quarterly30(2): 160-197.

Mintzberg, Henry, and James Waters. 1985. “Of Strategies, Deliberate and Emergent”. Strategic Management Journal 6(3): 257-272.

Mogherini, Federica. 2015a. 'The European Union in a changing global environment: A more connected, contested and complex world' Brussels: EEAS. Accessed 8 June 2018. http://eeas.europa.eu/archives/docs/docs/strategic_review/eu-strategicreview_executive_summary_en.pdf

2015b.Remarks by High Representative/Vice-President Federica Mogherini at the EUISS Annual Conference. 9 October. Accessed 8 June 2018.https://europa.eu/ globalstrategy/en/remarks-high-representativevice-president-federica-mogherinieuiss-annual-conference. 
New York Times. 2014."Bosnian Elections Reinforce Longstanding Ethnic Divisions”. 14 October. Accessed 8 June 2018.http://www.nytimes.com/2014/10/15/world/ europe/bosnian-elections-reinforce-longstanding-ethnic-divisions.html?_r=0 .

Novotnà, Teresa. 2017“'The EU as a Global Actor: United We Stand, Divided We Fall”. Journal of Common Market Studies. Annual Review. 55(S1): 177-191.

OHR. 1995. General Framework Agreement for Peace in Bosnia Herzegovina. 14 December. Sarajevo: Office of the High Representative. Accessed 8 June 2018. https://www.osce.org/bih/126173?download=true

von Ondarza, Nicolai, and Ronja Scheler. 2017. "The High Representative's 'Double Hat': How Mogherini and Ashton have Differed in their Links with the Commission". LSE EUROPP (London: LSE).

Overhaus, Marco. 2009."Operation Althea and the EU Police Mission in Bosnia and Herzegovina: implementing the comprehensive approach". In The EU as a strategic actor in the realm of Security and Defence? Edited by Muriel Asseburg and Ronja Kempin. SWP Policy Paper. Berlin: Stiftung Wissenshaft und Politik.

Pannier, Alice. 2013. "Understanding the workings of interstate cooperation in defence: an exploration into Franco-British cooperation after the signing of the Lancaster House Treaty". European Security 22(4): 540-558.

Peen Rodt, Anne Marie, and Stefan Wolff. 2012."European Union Conflict Management in the Western Balkans". Civil Wars 14(3): 414-30.

Radaelli, Claudio. 2003“'Theorizing Europeanisation”. In The Politics of Europeanisation, edited by Kevin Featherstone and Claudio Radaelli, 27-56 . Oxford: Oxford University Press.

Radio Free Europe. 2013. “Ashton Says Serbia, Kosovo Reach Deal”. 19 April. Accessed 8 June 2018. http://www.rferl.org/content/eu-serbia-kosovotalks/24962271.html.

Rynning, Sten. 2011. "Realism and the Common Security and Defence Policy". Journal of Common Market Studies 49(1): 23-42.

Shepherd, Alistair. 2003. “The European Union's Security and Defence Policy: A policy without substance?" European Security 12(1): 29-63.

Simòn, Luis. 2011. “Crisis Management Just Won't Cut it Anymore: military planning and CSDP after Lisbon". In "EUnity of Command: the planning and conduct of 
CSDP Operations." Egmont Paper 41, edited by Luis Simòn and Alexander Mattelaer. Brussels: Egmont Institute Academic Papers.

Sjöstedt, Gunnar. 1977“'The Exercise of International Civil Power: A Framework for Analysis". Cooperation and Conflict 12(1): 21-39.

SMD. 1998. Joint Declaration issued at the French-British Summit at Saint-Malo, 3-4 December. Paris: EU Institute for Security Studies. Accessed 8 June 2018. https://www.cvce.eu/content/publication/2008/3/31/f3cd16fb-fc37-4d52-936fc8e9bc80f24f/publishable_en.pdf.

Smith, Karen. 2005“'Still a Civilian Power EU?”. European Foreign Policy Unit Working Paper 2005/1. London: London School of Economics.

-..-- 2008. European Union Foreign Policy in a Changing World. Cambridge: Polity.

Smith, Michael E. 2004.Europe's Foreign and Security Policy: the institutionalization of Cooperation. Cambridge: Cambridge University Press.

2012. "Developing a 'Comprehensive Approach' to International Security: Institutional Learning and the CSDP". In Constructing a Policy-making State? Policy Dynamics in the EU, edited by Jeremy Richardson. Oxford: Oxford University Press.

Solana, Javier. 2003. 'A Secure Europe in a Better World: European Security Strategy' Paris: European Union Institute for Security Studies Accessed 8 June 2018. https:// europa.eu/globalstrategy/en/european-security-strategy-secure-europe-better-world

2007a. "From Cologne to Berlin and Beyond: Operations, institutions and capabilities". Address to the ESDP Conference. Berlin, 29 January.

Sus, Monika. 2014."The High Representative and the European External Action Service." In New Approaches to EU Foreign Policy, edited by Maciej Wilga and Ireneusz Pawel Karolewski,56-85. London: Routledge.

Sweeney, Simon, and Neil Winn. 2017. "CSDP and the Open Method of Coordination: Developing the EU's Comprehensive Approach to Security”. Journal of Regional Security 12(2): 95-122.

Telegraph. 2016. "Islamic State setting up terror training camps in Europe, police agency warns' London: The Telegraph 25 January. Accessed 8 June 2018.http://www. telegraph.co.uk/news/worldnews/islamic-state/12120636/Islamic-State-setting-upterror-training-camps-in-Europe-police-agency-warns.html. 
Toje, Asle. 2008. “The Consensus-Expectations Gap: Explaining Europe's Ineffective Foreign Power". Journal of Common Market Studies 49(1): 43-60.

2011. “The European Union as a Small Power”. Journal of Common Market Studies 49(1): 43-60.

Treaty of Lisbon. 2007. Official Journal of the European Union C 306. Vol.50, 7

December. Accessed 8 June 2018. http://eur-lex.europa.eu/LexUriServ/LexUriServ. do?uri=OJ:C:2007:306:FULL:EN:PDF.

United Nations. 2015. Security Council, Adopting Resolution 2247 (2015), Renews Authorization for European Union-Led Stabilization Force in Bosnia and Herzegovina. Accessed 8 June 2018. http://www.un.org/press/en/2015/sc12114.doc. htm.

2016. Security Council, Adopting Resolution 2315 (2016) Renews Authorization for European Union-Led Stabilization Force in Bosnia and Herzegovina Accessed 8 June 2018. https://www.un.org/press/en/2016/sc12580.doc. htm.

Urry, John. 2008. Mobilities. Malden, MA: Polity Press.

Vanhoonacker, Sophie, Hylke Dijkstra, and Heidi Maurer. 2010“"Understanding the Role of Bureaucracy in the Security and Defence Policy: The State of the Art”. European Integration on-line Papers 14(S1).

Watanabe, Lisa. 2010. Securing Europe: European security in an American Epoch. Basingstoke: Palgrave Macmillan.

WBIF. 2014. Western Balkans Investment Framework 2014 Annual Report. Accessed 8 June 2018. file://C:/Users/Simon/AppData/Local/Packages/Microsoft. MicrosoftEdge_8wekyb3d8bbwe/TempState/Downloads/rapport_annuel_2014_cibo. pdf.

Weber, Max. 1964.The Theory of Social and Economic Organisation. New York: The Free Press.

1970. “The Essentials of Bureaucratic Organisation”. In Modern Sociology: Introductory Readings, edited by Peter Worsley, 265-69. Harmondsworth: Penguin Education.

Whitman, Richard. 2013. "The EU and Sub-Saharan Africa”. In Routledge Handbook of European Security, edited by Sven Biscop and Richard Whitman, 189-200. London: Routledge. 
Whitman, Richard, and Ana E. Juncos.2009. “The Lisbon treaty and the foreign, security and defence policy: reforms, implementation and the consequences of (non-)ratification". European Foreign Affairs Review 14(1): 25-46.

2010. "Relations with the Wider Europe". Journal of Common Market Studies 48 (Annual Review): 183-204.

-..-- 2011. "Relations with the Wider Europe". Journal of Common Market Studies 49 (Annual Review): 187-208.

2012 "The Arab Spring, the Eurozone Crisis and the Neighbourhood: A Region in Flux". Journal of Common Market Studies 50 (Annual Review): 147-61.

- 2013. "Stasis in Status: Relations with the Wider Europe". Journal of Common Market Studies 51 (Annual Review): 155-167.

-...-- 2014. "Relations with the Wider Europe". Journal of Common Market Studies 52 (Annual Review): 157-169.

Wilson, James Q. 1991. Bureaucracy: What Government Agencies Do and Why They Do it. New York: Basic Books Classics.

Witney, Nick. 2008. Re-energising Europe's Security and Defence Policy. London: ECFR. Accessed 8 June 2018. http://www.ecfr.eu/page/-/ECFR-06-REENERGISING_EUROPES_SECURITY.pdf

Zwolski, Kamil. 2012a. “The EU as an international security actor after Lisbon: Finally a Green Light for a Holistic approach?". Cooperation and Conflict 47(1): 68-87.

2012b. "The EU and a holistic security approach after Lisbon: competing norms and the power of the dominant discourse". Journal of European Public Policy 19(7): 988-1005. 